\title{
Current understandings of toxicity, risks and regulations of engineered nanoparticles with respect to environmental microorganisms
}

\author{
Krishnamoorthy Hegde ${ }^{1}$ - Satinder Kaur Brar ${ }^{1}$ - Mausam Verma ${ }^{1,2}$. \\ Rao Y. Surampalli ${ }^{3}$
}

Received: 18 May 2016/Accepted: 8 August 2016/Published online: 23 August 2016

(C) Springer International Publishing Switzerland 2016

\begin{abstract}
Engineered nanomaterials offer exciting application opportunities in diverse fields ranging from biomedical, agriculture, environmental, cosmetics to household commodities. Increasing use of nanomaterials in day-to-day applications has also increased their exposure to environment and ecosystems significantly, which has raised the concern for environmental safety due to their potential adverse and toxicological effects on microbial community. Although several risk and safety assessment studies to evaluate the fate of nanoparticle in the environment and their effect on living organisms are being carried out in the recent years, still the current knowledge on impact of these nanomaterials on microorganisms is limited. The present review comprehensively summarizes and interprets the impact of nanomaterials on microbial community. Further, the technical challenges associated with the nanotoxicity evaluation, data interpretation and environmental regulations with respect to engineered nanomaterials are discussed.
\end{abstract}

Keywords Nanotoxicity - Ecotoxicity · Risk assessment . Engineered nanomaterials

Satinder Kaur Brar

satinder.brar@ete.inrs.ca

1 INRS-ETE, Université du Québec, 490 Rue de la Couronne, Quebec, QC G1K 9A9, Canada

2 CO2 Solutions Inc., 2300, rue Jean-Perrin, Quebec, QC G2C 1T9, Canada

3 Department of Civil Engineering, University of NebraskaLincoln, N104 SEC P.O. Box 886105, Lincoln, NE 68588-6105, USA

\section{Introduction}

The unique properties of the engineered nanomaterials (ENMs) offer great promise to provide innovative technological solutions in diverse field of applications. Today, ENMs are increasingly being introduced into array of everyday products, such as health care, cosmetics, household appliances, broad spectrum antimicrobial agent and many other applications [44, 59]. The widespread use of nanoproducts also resulted in its rapid incorporation into the environment via various process routes, such as manufacturing, product use and waste disposal [39]. Several reports indicate that concentration of some of the ENMs, such as $\mathrm{TiO}_{2}$, fullerenes, nanosilver, $\mathrm{ZnO}$, carbon nanotubes (CNT), is significantly higher in the environment, and the evidence on potential toxic effects of ENMs on living organisms is constantly being accumulated. Exposure of hazards associated with ENMs could potentially impact the function of soil, sediment and aquatic microbial communities [14, 16]. The mechanism of uptake of ENMs by microbes, their environmental fate and persistence, adverse effects on metabolism and bioaccumulation in living organisms is still not completely understood. Moreover, our knowledge on the environmental and ecological impact of ENMs is limited and it significantly lags the pace of industrial growth of nanotechnology.

Risk assessment and toxicological studies of nanowastes on biological organisms is a very important segment of ecotoxicology and nanotechnology, which is essential to predict the effect of potential non-toxicity on living organisms so that the most efficient and effective action to prevent or remediate any detrimental effect of ENMs can be identified [35]. Unfortunately, due to the limited predictive power of ENMs, and unavailability of standard test 
methods to identify adverse effects of nanomaterials, understanding of the mechanism of interaction of ENMs with an organism at molecular or cellular level is largely unknown. In the recent years, a number of efforts have been made to assess the risk factors associated with ENMs in the environment to calculate environmental concentrations of nanoparticles along with some experimental approaches to study the fate of ENMs under natural conditions [57]. The reports on several such toxicological studies of ENMs on microorganisms summons the critical need to establish a competent evaluation process to predict the environmental behavior of ENMs and their impact on soil microbial communities.

The microbial communities in the soil play a pivotal role in ecological and agricultural perspective. They are directly related to several balanced processes in the environment, such as decaying of organic matter in the soil, nutrient recycling, bioremediation of pollutants and symbiotically associated with several terrestrial plants [60]. Thus, the knowledge on the interaction of nanomaterials with the ecologically important microbial communities is very important for the balanced harmony of the ecosystem. Nevertheless, limited data are available on the interaction of ENMs with the environmentally important microorganisms. This review mainly focuses on the impact of ENMs on ecologically relevant microorganisms. Further, the present review summarizes and interprets the current knowledge status of the impact of nanomaterials on microbial community and the technical challenges associated with the nanotoxicity evaluation and data interpretation.

\section{Toxicity of ENMs to microbial community}

\section{Route and fate of ENMs in environment}

The technical advantages of the ENMs are attributed to their unique properties, such as small size, shape, chemical composition, solubility, surface structure and aggregation, which significantly differ from the properties of the bulk materials of same composition ([4, 44]). However, the same properties also contribute to their catastrophic fate in the environment and negative impact on microorganisms $[35,36]$. Several studies focusing on the exposure modeling of the ENMs suggest that the ENMs concentration is higher in soil than in water or air, indicating the soil to be the major sink for the ENMs released into environment [16, 31, 47, 84]. For example, discharged nanowastes may undergo sorption with organic matter and biomass, aggregate or interact with other compounds or even undergo microbial biotransformation $[9,19,46]$. Further, the transport of ENMs with particle size $<100 \mathrm{~nm}$ through porous media has higher mobility efficiency in the environment and is influenced by environmental conditions and Brownian diffusion $[19,65,67,70]$. It is also true that the natural organic matter in the aqueous environment plays a crucial role in transport of ENMs due to their inclination toward colloidal absorption and aggregation via hydrophobic interactions. Thus, ENMs in the environment are influenced by several factors listed earlier, which may change its properties leading to altered bioavailability. On the contrary, it has also been reported that sorption of ENMs to biosolids in wastewater might be hindered in the presence of surfactants in effluent discharge [19, 40, 46].

\section{Mechanism of ENM toxicity to microbial communities}

Scientific knowledge gathered on the interaction of ENMs with biological systems in the environment indicates that they can bind and interact with biological matter and change their surface characteristics. Studies have also shown that biological cells can readily take up nanoparticles via active or passive mechanisms. Figure 1 shows various transformations of ENMs in the environment.

Microbial communities are exposed to ENMs at various levels in the environment, such as water, sewage, soil and sediments. The ENMs may have impact on microbial communities by various mechanisms, such as: (1) direct toxic effects, (2) indirect effects as a result of their interaction with natural organic compounds, (3) enhancing the toxicity of persistent organic pollutants in soil and water by interacting with them and (4) by changing the bioavailability of toxins or nutrients $[16,78]$. Although the exact mode of toxicity of ENMs on microbial communities is still not completely understood, some of the possible mechanisms include: (1) damage of cell membrane; (2) oxidation of proteins; (3) genotoxicity; (4) interaction with respiratory chain and local proton depletion and; (5) reactive oxygen species (ROS) production and/or apoptosis $[16,36]$. The mechanisms of antimicrobial action of ENMs are summarized in Fig. 1.

In most of the studies reported so far, the concept of ENM toxicity to the microorganisms is largely centered on cellular level mechanisms as discussed earlier, which describes the cellular function of the affected microorganisms. However, there are very little data available on the nanomaterial interaction at molecular level. For instance, the interaction of ENMs with Gram positive and Gram negative bacteria differs as the phospholipid bilayer, lipopolysaccharides and peptidoglycan composition of the cell wall in these organisms are different, thus, leading to different interactions and varied level of toxicity. This is also supported in recent reviews. Tegou et al. [82] and Zou et al. [95] reviewed that cell wall composition and charges on the bacterial cell wall largely attribute to the adhesion of 
Fig. 1 Illustration of the dynamic transformations of ENMs in the environment and their impact on microorganisms (modified from [19, 57]

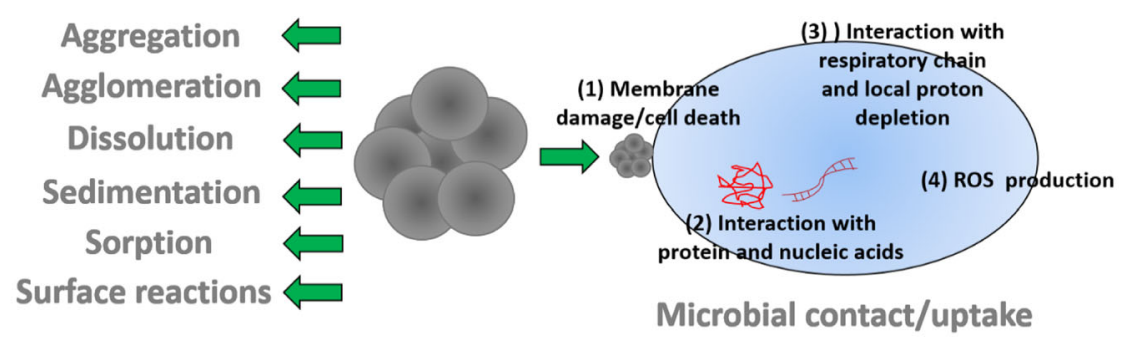

Fate of ENMs in the environment
Impact of ENMs on microbial community graphene nanomaterials and subsequent phenomenon of bacterial toxicity.

Though the toxicological effects of ENMs on pathogenic and ecologically relevant microorganisms are similar, the issue that raises severe concern is their toxicity to microorganisms that are beneficial to plant and those involved in the nutrient mineralization, nitrogen cycling and organic carbon degradation in soil. For example, ENMs such as $\mathrm{TiO}_{2}, \mathrm{ZnO}, \mathrm{CuO}, \mathrm{Ag}$, carbon nanotubes (CNTs) and fullerenes have been shown to reduce soil microbial communities and plant growth promoting microbial consortium, such as rhizobacteria and mycorrhiza. In some cases, the ENMs dissolve in the soil solution (Cuo, $\mathrm{ZnO}$ ) or seawater (Ag) and affect the microbial community by a well-known mechanism of metal ion toxicity to cells [29, 39, 73, 85].

Rapid, reliable and cost-effective analytical methods for detection of ENM-microbial interaction are also very important for understanding the mechanism of interaction and the safe use and monitoring of nanomaterials in the environment. Several sophisticated spectroscopic methods, such as Fourier transform infrared spectroscopy (FTIR), nuclear magnetic resonance spectroscopy (NMR), mass spectrometry, Raman spectroscopy are being used for studying the microbial interaction and changes in the intercellular composition of the microorganisms [23]. The methods, such as FTIR, are highly reliable to assess the microbial interactions with nanomaterials at molecular level. However, most of these methods are time-consuming and not cost-effective. Further, these methods also need special instrumental infrastructure and skilled manpower for the analysis, which might not be available in most of the research laboratories. Further, the real-time monitoring of the microbial interaction in the soil and water might not be possible. In a recent study, Suppi et al. [81] proposed a simple and effective 'spot test' for the evaluation of biocidal effect of ENMs under the same test conditions for various organisms, such as bacteria, fungi and algae. In this test assay, the organisms were exposed to ENMs in deionized water to reduce the speciation-related effects on toxicity results and further cultured on agarized medium to study the lethal effect of ENMs. The study involved environmental and clinical specific bacterial strains, namely E. coli MG1655, $S$. aureus RN4220, $P$. fluorescens OS8, P. aeruginosa DS10-129, Janthinobacterium sp, Microbacterium testaceum PCSB7 and eukaryotic microorganism, Saccharomyces cerevisiae BY4741 and microalga Pseudokirchneriella subcapitata. The biocidal potency of different ENMs of various compositions, such as $\mathrm{Ag}, \mathrm{CuO}$ and $\mathrm{TiO}_{2}$ and MWCNTs, revealed that the mechanism of toxicity is similar among the organisms, irrespective of type of microorganisms. The facts indicate that in the environment, where the microorganisms are not protected from toxic chemicals, the level of tolerance to ENMs is rather chemical dependent than the type of organisms. Though the test method is reliable for 'quick' evaluation of toxicity of ENMs on various microorganisms under laboratory conditions, the method might not be accurate for real-time monitoring of the toxicity in the environment due to the fact that the bioavailability of the ENMs is influenced by several factors in the environment, which may change the properties of ENMs.

The following section briefs the recent toxicological studies relevant to some class of ENMs, which are abundantly used in various consumer products and other applications. Table 1 further summarizes the effect of some of the engineered nanoparticles on microorganisms.

\section{Toxicity of silver nanoparticles (Ag-NPs)}

Ag-NPs are one of the most commonly used antimicrobial nanomaterials in range of consumer products and for medical applications. The release of Ag-NPs into the environment may have negative impact on the environmental microorganisms responsible for the various biogeochemical cycle in the environment. Various studies indicate that Ag-NPs interfere with cell membrane integrity of microorganisms [1, 33]. Toxicological effect of Ag-NPs on ecologically important bacteria, such as nitrifying bacteria (Nitrosomonas and Nitrobacter), Escherichia coli, Pseudomonas aeruginosa, Staphylococcus aureus and Bacillus subtilis, has been extensively studied for pure culture media $[5,7,11,49,66,80]$. For instance, Beddow et al. [7] studied the effect of capped and uncapped 
Table 1 Effect of some of the engineered nanoparticles on the microorganisms

\begin{tabular}{|c|c|c|c|}
\hline Nanoparticle & Microorganism & Effects & References \\
\hline Ag-NPs biosynthesized by fungi & $\begin{array}{l}\text { Fungus (Aspergillus niger) and } \\
\text { bacterial strains } \\
\text { (Staphylococcus sp., Bacillus } \\
\text { sp. and E. coli) }\end{array}$ & Toxicity & Rajkishore et al. [71] \\
\hline $\operatorname{Ag} 0$ & Escherichia coli & MIC $100 \mu \mathrm{g} / \mathrm{ml}$ & Chudasama et al. [12] \\
\hline AgNPs & Escherichia coli & 33-45\% damaged $E$. coli cells & Beddow et al. [7] \\
\hline AgNPs & Chlamydomonas reinhardtii & Toxicity & Navarro et al. $[62,63]$ \\
\hline AgNPs & $\begin{array}{l}\text { Heterotrophic (rhizobacteria), } \\
\text { chemolithotrophic and soil } \\
\text { formation bacteria }\end{array}$ & Toxicity & Throback et al. [83] \\
\hline $\begin{array}{l}\text { Aqueous graphene oxide/reduced } \\
\text { graphene oxide dispersions }\end{array}$ & Enterococcus faecalis & ROS production & Tegou et al. [82] \\
\hline $\begin{array}{l}\text { Aqueous graphene oxide/reduced } \\
\text { graphene oxide dispersions }\end{array}$ & Bacillus subtilis & Cell membrane disruption & Tegou et al. [82] \\
\hline $\begin{array}{l}\text { Aqueous graphene oxide/reduced } \\
\text { graphene oxide dispersions }\end{array}$ & Escherichia coli & Growth inhibition & Tegou et al. [82] \\
\hline $\begin{array}{l}\text { C60 nanoparticle aggregates } \\
(\text { (nC60) }\end{array}$ & Escherichia coli & Toxicity & Lyon and Alvarez [55] \\
\hline CdSe QDs (quantum dot) & Escherichia coli & Toxicity & Pokhrel et al. [68] \\
\hline CdSe/ZnS QDs & Nitrosomonas europaea & Toxicity & Yang et al. [91] \\
\hline CdSe/ZnS QDs & Pseudomonas aeruginosa & Toxicity & Yang et al. [93] \\
\hline $\mathrm{CeO}_{2}$ & Escherichia coli & Toxicity & Pelletier et al. [66] \\
\hline $\mathrm{CeO}_{2}$ & Shewanella oneidensis & Toxicity & Pelletier et al. [66] \\
\hline $\mathrm{Cu}$-doped $\mathrm{TiO}_{2}$ & Shewanella oneidensi & Toxicity & Wu et al. [90] \\
\hline $\mathrm{CuO}$ & $\begin{array}{l}\text { Plant growth promoting strains } \\
\text { (Klebsiella pneumonia, } P . \\
\text { aeruginosa, Salmonella } \\
\text { paratyphi and Shigella) }\end{array}$ & Antibacterial activity & Rajkishore et al. [71] \\
\hline $\mathrm{CuO}$ & Bacillus subtilis & Toxicity & Baek and An [6] \\
\hline Graphene & Escherichia coli & Antimicrobial & Zou et al. [95] \\
\hline $\begin{array}{l}\text { Graphene oxide conjugated with } \\
\text { silver nanoparticle }\end{array}$ & Escherichia coli & Cell membrane disruption & Tegou et al. [82] \\
\hline $\begin{array}{l}\text { Lithium Nickel Manganese Cobalt } \\
\text { Oxide }\end{array}$ & Shewanella oneidensis MR-1 & $\begin{array}{l}\text { Significant impair in cell } \\
\text { growth and respiration at } \\
\text { conc. of } 5 \mathrm{mg} / \mathrm{L}\end{array}$ & Hang et al. [34] \\
\hline $\begin{array}{l}\text { Multiwalled carbon nanotubes } \\
\text { (MWCNT) }\end{array}$ & Escherichia coli & Toxicity & Simon-Deckers et al. [77] \\
\hline $\begin{array}{l}\text { Nanozerovalent iron particles } \\
\text { (nZVI) }\end{array}$ & Escherichia coli & Bactericidal effect & Lee et al. [48] \\
\hline Nanosilverparticles(Ag0) & Escherichia coli & $\begin{array}{l}\text { Minimum inhibitory } \\
\text { concentration (MIC) of } \\
1 \mu \mathrm{g} / \mathrm{ml}\end{array}$ & Vertelov et al. [89] \\
\hline nC60 & Bacillus subtilis & Toxicity & Lyon and Alvarez [55] \\
\hline $\begin{array}{l}\text { Polymer nanocomposites with } \\
\text { carbon nanotubes }\end{array}$ & Pseudomonas aeruginosa & Cytotoxicity & Goodwin et al. (30) \\
\hline $\begin{array}{l}\text { Reduced graphene oxide } \\
\text { conjugated with silver } \\
\text { nanoparticle }\end{array}$ & Pseudomonas aeruginosa & Growth inhibition & Tegou et al. [82] \\
\hline $\mathrm{Sb}_{2} \mathrm{O}_{3}$ & Bacillus subtilis & Toxicity & Baek and An [6] \\
\hline Silver nanoparticles (AgNPs) & $\begin{array}{l}\text { Ammonia-oxidizing bacteria } \\
\text { (Nitrosomonas europaea, } \\
\text { Nitrosospira multiformis and } \\
\text { Nitrosococcus oceani) }\end{array}$ & $\begin{array}{l}\text { Significant inhibition to the } \\
\text { nitrification potential rates }\end{array}$ & Beddow et al. [7] \\
\hline
\end{tabular}


Table 1 continued

\begin{tabular}{|c|c|c|c|}
\hline Nanoparticle & Microorganism & Effects & References \\
\hline $\mathrm{SiO}_{2}$ & Escherichia coli & Toxicity & Li et al. [50] \\
\hline $\mathrm{SiO}_{2}$ and $\mathrm{CeO}_{2}$ & $\begin{array}{l}\text { Pseudokirchneriella } \\
\text { subcapitata }\end{array}$ & $\begin{array}{l}\text { Toxicity and decreased } \\
\text { photosynthetic activity }\end{array}$ & Van Hoecke et al. $[87,88]$ \\
\hline $\mathrm{TiO}_{2}$ & Anabaena variabilis & $\begin{array}{l}\text { Disruption of cellular structure } \\
\text { and components; generation } \\
\text { of ROS; impact on ecological } \\
\text { food web }\end{array}$ & Cherchi et al. [10] \\
\hline $\mathrm{TiO}_{2}$ & Vibrio fischeri & Toxicity & Heinlaan et al. [37] \\
\hline $\mathrm{TiO}_{2}$ & Pseudomonas aeruginosa & Toxicity & Hessler et al. [38] \\
\hline $\mathrm{ZnO}$ & Escherichia coli 1313 & $\begin{array}{l}0.1 \mathrm{mg} / \mathrm{ml} \text { for } 1 \mathrm{~h} ; 92 \% \\
\text { inhibition }\end{array}$ & Applerot et al. [3] \\
\hline $\mathrm{ZnO}$ & Escherichia coli & $\begin{array}{l}100 \% \text { mortality at } 20 \mathrm{mg} / \mathrm{l} \\
\mathrm{ZnO}\end{array}$ & Jiang et al. [42] \\
\hline $\mathrm{ZnO}$ & Escherichia coli $\mathrm{O} 157: \mathrm{H} 7$ & $960 \mathrm{mg} / \mathrm{l} ; 100 \%$ inhibition & Liu et al. [52] \\
\hline
\end{tabular}

nanosilver, and $\mathrm{Ag}_{2} \mathrm{SO}_{4}$ on the activities of various ammonia-oxidizing (viz., Nitrosomonas europaea, Nitrosospira multiformis and Nitrosococcus oceani) and other bacteria (Escherichia coli and Bacillus subtilis) and found that all Ag-NPs treatments caused significant inhibition to the nitrification potential rates and growth of the bacteria. The inhibitory effect on the growth of all the bacteria was found to be in the order of $\mathrm{Ag}_{2} \mathrm{SO}_{4}>$ capped nanosilver $>$ uncapped nanosilver. However, data obtained by such laboratory experiments from pure microbial culture are often challenging to extrapolate to the natural environments. An exposure to natural environment, such as soil and sediment systems may provide additional sink to ENMs to reduce or enhance their bioavailability. Thus, it would be more appropriate to validate the toxicological assessment in the adsorbent system, such as soils and sediments [56].

Studies with bacterial enrichment cultures reproduced from surface sediments suggest that Ag-NPs interfere with the nitrogen cycle in the aquatic environment and reduce the ammoxidation due to their toxic effect on ammonia-oxidizing bacteria [54]. Apparently, Ag-NPs inhibit the growth of ammonia-oxidizing bacterial biodiversity due to their antibacterial property which leads to the reduction in ammoxidation. On the contrary, similar studies with Au-NPs showed no notable reduction in ammoxidation [54]. Similar concentration-dependent inhibitory effect of Ag-NPs on soil nitrification process mediated by nitrifying bacteria in an agricultural soil has also been reported by Masrahi et al. [56]. Several mechanisms have been reported for the toxicity of Ag-NPs on microorganisms. Number of studies have shown that toxicity of Ag-NPs is caused by the release of $\mathrm{Ag}^{+}$which interfere with functional proteins, such as ATP synthase, monooxygenase and hydroxylamine oxidoreductase
[56, 92]. However, there are also reports on other modes of action, such as destabilization of the outer membrane, decrease in intracellular adenosine triphosphate (ATP) levels [43, 53] and generation of ROS [11].

\section{Toxicity of carbonaceous nanomaterials (CNMs) and quantum dots $(Q D)$}

There are limited data available on the removal of CNMs, such as CNTs, graphene and QDs from the wastewater treatment plants (WWTPs), which ultimately end up in the environmental matrices. Moreover, the present WWTPs are not efficient enough to remove these ENMs to satisfactory level due to the technical challenges and barriers in quantification of them in the wastewater treatment process [94]. However, there are sufficient data to state that these materials are released to the environment in various stages of the synthesis lifecycle and usage to cause adverse effect on the environmental microorganisms. For instance, the interaction and toxicity of the graphene is influenced by various factors, which can be categorized into intrinsic or physiochemical properties of the graphene and surrounding/environmental factors. Firstly, the intrinsic properties, such as lateral size, number of layers, size, surface modifications and agglomeration/Dispersion properties, greatly determine the antimicrobial properties of graphene [95]. In addition, various parameters of the surrounding environment, such as aerobic and anaerobic conditions, state of the medium (liquid or solid) and mode of experiment (in vivo and in vitro), also influence the antimicrobial intensity on particular microorganism. Similarly, CNMs may also be directly toxic to soil microorganisms or they may interfere with the nutrient bioavailability or alter the toxicity of the organic compounds in the soil. There are also possibilities of indirect impact of ENMs on symbiotic microorganisms 
when they are toxic to plants [60]. For instance, $\mathrm{C}_{60}$ have been found to inhibit the growth of commonly occurring soil and water bacteria. The hydroxylated forms of $\mathrm{C}_{60}$ or $\mathrm{C}_{60}$ coated polyvinyl pyrrolidone ENMs can act as potent oxidizing agents in biological systems due to generation of singlet oxygen that can cause lipid peroxidation and cell damage [41]. Effects of $\mathrm{C}_{60}$ and CdSe quantum dots (QD) on microbial catalyzed oxidation of organic matter in freshwater sediments focusing on their effect on acetate oxidation by nitrate-reducing bacteria revealed that $\mathrm{C}_{60}$ at concentration of $140 \mu \mathrm{g}$ per liter completely inhibited the microbial oxidation of acetate and CdSe QD at concentration of $200 \mu \mathrm{g}$ per liter negatively affected the rate of acetate oxidation in the sediment slurries [28]. Some of the studies indicate that the toxicity of QDs to bacteria is primarily due to the release of harmful components, such as heavy metals or ions, which they possess in their core or shells [28]. However, detailed reports available on the stability and dissociation of quantum dots in the environment and their potent toxic effects on microbial communities are sparse.

CNTs are generally considered to be toxic to soil microorganisms regardless of the composition and functionalization of the CNTs $[30,60]$. Studies suggest that direct contact of microorganisms with highly purified CNT aggregates leads to decrease in cell viability and cell death $[13,45,77]$. Physical piercing and oxidative stress are the general mechanism associated with cytotoxicity of CNTs [45]. Studies with antimicrobial effect of CNTs on pure culture of microorganisms also suggest that they negatively affect the bacterial growth [13]. Chung et al. [13] investigated the effect of multiwall carbon nanotubes (MWCNTs) on the activity and biomass of soil microorganisms. The study revealed that at a concentration of $500 \mu \mathrm{g}$ MWCNT per gram soil, most of the enzyme activities, such as $1,4-\beta-$ glucosidase, cellobiohydrolase, xylosidase, 1,4-b-Nacetylglucosaminidase, and phosphatase, were repressed and at concentration of $500 \mu \mathrm{g}$ MWCNT per gram soil all enzymatic activities as well as microbial biomass was significantly lowered [13] indicating the toxic effect of MWCNTs on microorganisms and their metabolic process. Similar antimicrobial effect of MWCNTs on soil microorganisms has also been reported for culture studies $[45,77]$. Studies on effect of single-wall carbon nanotubes (SWCNTs) on pure E. coli and soil with low or high organic contents showed that it can affect the microbial community and induce changes in soil metabolic activity in the low organic matter systems [85]. Toxicology study consisting of SWCNTs either as raw or functionalized with polyethyleneglycol or m-polyaminobenzene sulfonic acid exposed to soil microbial community for 6 weeks showed that repeated exposure of raw SWCNTs is toxic to the metabolic activity of bacteria [85]. Similarly, polymer nanocomposites of carbon nanotubes (PNC) are proven to be toxic to Pseudomonas aeruginosa [30].

\section{Toxicity of metal oxide-based nanoparticles}

Metal oxide-based nanoparticles have been proven to be toxic to soil microorganisms. Numerous reports and reviews are available on the toxicity of $\mathrm{Zn}-, \mathrm{Cu}-$, Ti-based metal oxide nanoparticles, which are most common and largely used metal oxide nanoparticles in various commodities. In addition, various lanthanide oxide-based nanoparticles (LnONps), such as dysprosium oxide nanoparticle (nDy2O3), which are increasingly being used in the biomedical fields have adverse effect on natural biological systems and interfere with the metabolic activity and structural integrity of the microorganisms, such as E. coli [2]. Rousk et al. [74] studied the ecotoxicity of Znand $\mathrm{Cu}$ oxide-based nanoparticles on soil bacterial consortium using soil samples. In addition to $\mathrm{Zn}$-and $\mathrm{Cu}$ oxidebased nanoparticles, the study also used two referral compounds, namely bulk oxide of non-nanoparticulate form and highly soluble sulfate forms of the metals to elucidate if any observed toxicity was due to its nanoparticulate form, or due to metal ion solubilization in soil solution. Further, the study revealed that $\mathrm{CuSO}_{4}$ is highly toxic to soil bacteria in comparison with its oxide forms and the bulk (macroparticulate) form of $\mathrm{CuO}$ was nontoxic. In contrast, all forms of $\mathrm{Zn}$ were toxic to soil bacteria with highest toxicity for bulk-ZnO form compared to nano$\mathrm{ZnO}$. The study also showed a strong correlation between dissolved concentration of metals in solution and the bacterial growth, and the principle mechanism of toxicity was due to dissociation of metal oxides and sulfides into their corresponding metal ion form, which is toxic to the microorganisms. A comparative analysis of ecotoxicity of $\mathrm{TiO}_{2}, \mathrm{SiO}_{2}$ and $\mathrm{ZnO}$ nanoparticles to Bacillus subtilis and Escherichia coli showed that the antibacterial activity generally increased from $\mathrm{SiO}_{2}$ to $\mathrm{TiO}_{2}$ to $\mathrm{ZnO}$, and $B$. subtilis was highly susceptible to such toxic effects [72]. Further, the effect of nanoparticle may be different at in vivo and in vitro level in microorganisms. Recent study on effect of $\mathrm{TiO}_{2}$ nanoparticle $(10-100 \mathrm{~nm}$ size) on the intestinal commensal bacteria in Drosophila showed that it could inhibit the growth of intestinal bacteria in the dosage and particle size-dependent manner in vitro in the cultured bacteria [51]. However, same dosage and particle size of the $\mathrm{TiO}_{2}$ had no antibacterial effect on the gut bacteria of the Drosophila (in vivo). The study also showed another surprising phenomenon that the inhibition was independent of photocatalytic activation of $\mathrm{TiO}_{2}$. Commonly, $\mathrm{TiO}_{2}$ inhibits the bacterial growth by photocatalytic activation, which results in ROS and $\mathrm{H}_{2} \mathrm{O}_{2}$ formation due to UV radiation leading to cell death. Similar parameters also 
influence the metal oxide-based ENMs in the environment. The toxicity governing factors in the environment include concentration and form of organic matter in soil (which increase the tendency of ENMs to form aggregates and interaction with biomolecules), effective cation exchange capacity of ENMs, which is influenced by soil $\mathrm{pH}$, [74]. However, it is also true that different bacterial orders are affected differently in the soil $[15,26]$.

Nickel manganese cobalt oxide nanoparticle (NMC) is a new class of nanomaterial used in the battery components. Due to its higher performance and lower cost, it is being widely considered for the applications in the batteries of the electric vehicles. However, the recent toxicological studies showed that as low as $5 \mathrm{mg} / \mathrm{L}$ of NMC is lethal for the bacterial growth and respiration for soil bacteria, Shewanella oneidensis MR-1 [34]. The toxicological study with NMC sheet-like structure revealed that the toxicity is largely due to the partial incongruent dissolution of NMC rather than $\mathrm{NMC}$ itself, which release $\mathrm{Li}^{+}, \mathrm{Ni}^{2+}$ and $\mathrm{Co}^{2+}$, responsible for toxicity of globally distributed soil microorganisms, such as Shewanella oneidensis MR-1. The mechanism of the toxicity showed that the released metal ions, such as $\mathrm{Co}^{2+}$ and $\mathrm{Ni}^{2+}$ are the essential trace elements for the microorganisms, and they enter the cells by specific uptake pathways meant to bring them inside the cells. However, large concentration of these metal ions in the cell leads to several impaired activities in the cell, such as binding to protein and compete with the metal cofactors of metalloenzymes and even the damage to DNA, which causes the cell death [34]. This fact is also evident from various other in vitro and in vivo studies that showed nickel disrupting the activity of metalloenzymes, such as dioxygenase (Fe-dependent enzyme) by replacing the iron ion by nickel(II) ion to inhibit the catalytic activity. Nickel exposure also interfered with the activity of the superoxide dismutase (SOD) in microorganisms, such as B. vietnamiensis, P. putida and E. coli by inducing oxidative stress. It is evident from numerous studies that the microbial toxicity in the environment due to ENMs need not be due to their mere exposure as nanoparticle, but also could be due to the series of transformation cycles of the nanomaterials, which could lead to devastating fate of the environmental microorganisms. This is also the reason that makes developing 'universal' method for risk assessment of any type of nanomaterials so far manufactured, highly challenging.

In contrast to the studies revealing toxic effects on microbial communities as discussed in the earlier sections, there are several reports indicating the beneficial effects of ENMs on bacterial growth, probably due to the very same properties which cause toxicity, such as large specific surface area and capacity to release electrons. It has also been reported that electrons generated by nanoparticles may enhance enzymatic function of external membrane proteins, may speed up electron transport chain function, and facilitate cell metabolism. Some of the studies have also shown no noticeable influence of nanoparticles on bacteria $[25,58]$.

\section{Safety and risk assessment aspects for ENMs}

\section{Challenges in the risk assessment of ENMs}

Risk assessment is a task of characterizing the level of risk, typically in terms of a relative ranking. The prime objective of carrying out a risk assessment is to deliver information that will be helpful to evaluate alternatives [20,35]. The steps in the risk assessment of ENMs (i.e., hazard identification, hazard characterization, exposure assessment and risk characterization) remain so far the same as that of the methods used for the risk assessment of hazardous chemicals. In brief, the steps of this process involve identification and characterization of the hazards, establishing the link between dose and response for various end points, and then predict the probability of exposure. However, this process becomes complicated when it comes to nanomaterials. First of all, ENMs are not a uniform group of materials [8], secondly, the elemental composition of different nanoparticles and their properties, such as surface area, characteristics of the surface, tendency to aggregate and surface charge, are completely different from one form of nanomaterial to other. Thirdly, nanomaterials are manufactured from various materials in different forms and sizes and often with different coatings. Thus, the risk assessment of such diverse materials requires standard validation methods for both final product and their bulk samples which makes it difficult to set a standard protocol and significantly complicates the risk assessment process of ENMs [75].

Another important issue that needs thorough attention is related to possible exposure of ENMs to the environment during the entire production life cycle. Though it is true that most of the products are not likely to cause exposure as long as they are embedded in the matrices or polymers [75], the scenario may reverse during the processing and usage. Studies have shown that ENMs may undergo agglomeration, aggregation, adhesion, diffusion, dissociation, degradation, adsorption upon release into the environment finally leading to bioaccumulation and biomagnification in trophic pyramids [27]. The tendency of nanoparticles to undergo above-said processes depends on their properties as well as the local environmental and cellular conditions $[27,64]$. Thus, it is necessary that the toxicological evaluation process of ENMs includes all the factors, such as physical (size, shape, surface area and agglomeration state), chemical (chemical composition, 
charge and chemical reactivity), biological (route of administration, metabolism, excretion, adduction to biological molecules) and environmental (the presence of microbes, temperature, $\mathrm{pH}$, salinity, acidity, viscosity) factors [27].

Further, the lack of available data on persistence, mobility, bioavailability and ecotoxicity of ENMs makes it difficult to establish a standard protocol for testing their ecotoxicity. Recent studies have revealed that the existing theoretical methods and/or experimental protocols to detect and quantify the concentrations of nanoparticles in the environment are still at the very early stage of their development and effective methodologies are yet to be developed though several attempts are being done [27, 32, 76]. Most of the current data available on the microbial nanotoxicity have been drawn by traditional bacterial and microbiological assay to assess the toxicity, or by study of morphological changes and ROS generation using electron microscopy and fluorescent probes, respectively [57]. This indicates that very little data are available on behavior of ENMs in environmental matrices, such as water, air and soil, which makes it difficult to predict the interaction of nanoscale materials with microorganisms and the ultimate impact on ecosystem [27]. Furthermore, certain nanoparticles, such as Ag-NPs and $\mathrm{TiO}_{2}-\mathrm{NPs}$, are meant to exert toxic effects on pathogenic microorganisms as they are used as antimicrobial agents. Thus, their release into environment may inevitably and adversely affect the beneficial microbial communities such as nitrifying bacteria until and unless they are removed from the early stage of their release into environment. Thus, it is very important that the toxicity assessment studies focus on, characterization of ENMs in a complex, natural ecosystem at functional level and account for natural conditions that cause a known change to the ENMs characteristics, such as a natural occurring gradient of ionic strength or $\mathrm{pH}$ [57].

\section{Approaches for effective risk assessment of ENMs with respect to microorganisms}

The accumulating data on toxic effects of various nanomaterials on microorganisms and the poor state of knowledge related to the risk assessment of the ENMs warrant for the urgent need to develop alternative assessment procedures which are more efficient and stringent in evaluation.

One possible way to simplify the process is to focus on the main and relevant components of the large pool of data deriving exposure levels of ENPs through exposure assessment [69]. For instance, dividing ENPs to definite groups and types based on the size distribution consisting of finite size classes. This would help to address the issue of infinite numbers of ENM particle sizes discharging into environment. This also helps in representing the only one average particle size (such as average or medium particle size) in a better way during assessment [69]. In the similar way, ENMs coatings can be divided into different classes according to their properties, such as steric, electrostatic and electrostatic repulsion properties and mode of action [21, 79]. Another possible categorization is related to interaction of ENMs with the environment. For instance, once in the environment, ENMs encounter a wide range of components, such as suspended particulate matter, dissolved natural organic matter, biota, surfactants and metals, which can potentially interact and affect the ENMs' surface properties. Thus, categorizing the type of interactions, such as surface transformations, sorption, agglomeration, deposition, and then identifying the dominant process would help in prioritizing the research focus [69].

It is also crucial that the hazard assessment not only focuses on the concentration of the ENMs in the environment but also its properties and characteristics, such as size, shape and degree of aggregation. An array of sophisticated analytical techniques, such as microscopy, dynamic light scattering and size separation approaches combined with the detection methods like inductively coupled plasma MS, would be helpful in faster and efficient assessment. However, owing to the drawbacks of their own in each techniques, a combination of these techniques would be more helpful [84].

Another way of approach is to use computational methods to predict properties, reactivity and mechanisms of actions for various molecular systems. Methods such as Quantum chemical calculations and molecular dynamics (MD) simulations, Quantitative Structure-Activity Relationships (nano-QSAR) can aid to address the potential risks associated with nanomaterials [27]. Results from such theoretical data combined with experimental work might help in deciphering the complexity of ENM assessment [69].

\section{Environmental regulations/legislations for nanomaterials}

The current evaluation methods for the regulation of nanomaterials are not sufficient to deal with its unique issues and potential risks to the environment and health. The limited availability of exposure and hazard data is the prime hindrance in stringent law enforcement for nanomaterials. However, the situation is improving and the government agencies in many countries are actively involved in sorting out the issue. For instance, the US government proposed a budget of $\$ 2.1$ billion (which is \$201 million increase from the 2010 endorsed budget) for the multiagency national nanotechnology initiatives to understand the potential benefits and risks of nanomaterials [17]. 
In fact, countries, such as USA and Europe, are changing their approach toward regulation of nanomaterials. In USA, the nanomaterials are mainly regulated by Environmental Protection Agency (EPA) under the Toxic Substances Control Act (TSCA) and also Federal Insecticide, Fungicide, and Rodenticide Act (FIFRA). Other federal government agencies, like Food and Drug Administration (FDA) also regulates nanomaterials, sometimes in collaboration with EPA to monitor nanomaterials that appear in various categories of products, such as cosmetics, medical devices, drugs and food. The EPA has modified its approach toward regulation of nanomaterials. Earlier, the nanomaterial manufacturers were encouraged to provide volunteer information on nanomaterials through Nanoscale Materials Stewardship Program (NMSP); however, at present EPA has shifted toward mandatory approaches to collect detailed information to set standards on production, usage and safe disposal of nanomaterials, which includes Pre-manufacture notifications for new nanomaterials and stringent rule on gathering of information on new and existing nanomaterials [17, 86]. Under Pre-manufacture notification rule, TSCA seek specific information on new chemical substances for review on risk to environment and human health, prior to manufacture. Since 2015, EPA reviewed more than 160 new chemical substances under nanoscale materials, such as carbon nanotubes and agency, has taken several actions to control/limit such nanomaterials, like limiting the usage, use of appropriate personal protective equipment (PPE), limiting environmental release and need of testing to generate environmental and health effect data. Several nanoscale materials are limited to manufacture under consent order or Significant New Use Rules (SNUR) under TSCA [86]. Under information gathering rule, EPA is trying to gather more comprehensive information on nanoscale materials by urging the manufacturers to notify details of materials for one-time reporting and recordkeeping. The details, such as manufacturing volume, manufacture and processing method, details on exposure and environmental release as well as available health and safety data are expected to be furnished to EPA under TSCA rule before manufacturing such nanoscale materials [86]. EPA is also addressing several nanoscale pesticides under FIFRA. Nanomaterials intended to work on mitigation or prevention of pests and microorganisms are regulated under FIFA, which is working on modification of pesticide registration guidelines to know the nanomaterial ingredients in pesticides. Similar to EPA, FDA is also regulating nanomaterials that occur in various categories of cosmetics, food and medical products [24]. FDA has published various industrial guidelines for use of nanomaterials in cosmetics, food ingredients and food contact substances and color additives in food [24].

In European Union, the chemical management is mainly regulated under 'Registration, Evaluation, Authorization and Restriction of Chemicals' (REACH) regulations and Classification, Labeling and Packaging of Substances and Mixtures (CLP). At present, there are no particular regulations in European legislations targeting nanomaterials and the regulations of REACH on chemical substance do not clearly differentiate the nanomaterials with other chemicals. However, there has been a growing development in the nanotechnology regulations in Europe. In 2011, European Commission released specific recommendations to consider nanomaterials in different European regulations including REACH and CLP [18]. Further, the European Chemicals Agency (ECHA) in collaboration with other EU Member States published various guidance documents for accounting nanomaterials by industries, which would also facilitate registering the nanomaterials in REACH [22]. Similarly, several mandatory reporting and tracking systems are introduced in France under the Grenelle II Act and in Austria under Nanotechnology Action Plan for the safety of nanomaterials.

In Canada, there are no specific legislation on regulation of nanomaterials and they are regulated under various existing legislations, including Canadian Environmental Protection Act, 1999 (CEP), Pest Control Products Act (PCPA), Fertilizers, Feeds, Food and Drugs Act. However, the Canadian government is actively working on bringing changes in the nanomaterial regulations by funding and encouraging health and safety research on nanomaterial [61].

Asian nations are also actively participating and spending substantial resources in nanotechnology promotion and regulation schemes. The effort on conducting several survey reports on nanomaterial safety research is underway by the Ministry of Health, Labour, and Welfare (MHLW) and Ministry of the Environment (MOE) in Japan. The National Institute of Advanced Industrial Science and Technology (AIST) has also published important risk assessment data and reports on various nanomaterials, such as fullerenes, CNTs and $\mathrm{TiO}_{2}$ in effort to make regulations on nanomaterials [17]. The countries like Australia, Thailand and Korea are among others to pursue several regulatory strategies and policy initiatives to regulate nanomaterials.

\section{Concluding remarks}

Nanotechnology has furnished our life with wide range of products to make our life more comfortable. However, the increasing use of ENPs in consumer products has introduced several toxic group of compounds into the ecosystem, leaving a toxicological challenge to deal with. Although numerous reports available on the deleterious effect of ENMs on the ecologically important microbial 
communities, our research and current understanding of the interactions of ecological microorganisms at molecular level are limited by the cost-effective analytical methods. The present analytical and risk assessment methods and stringent regulations to tackle the problems of ENMs in the perspective of environmentally important microbial communities lag with the pace of nanotechnological industrial growth. A multidisciplinary approach combining experimental, computational and theoretical approaches would help in finding advanced effective risk assessment methods to tackle the ecotoxicological problems associated with engineered nanoparticles. Further, the research also needs to focus on sustainable analytical methods for real-time monitoring of the microbial interactions in the environment to understand and prevent the inadvertent negative impact of ENMs on microbial communities.

Acknowledgments Financial assistance by the 'Fonds de recherche du Québec-Nature et technologies (FRQNT)' and INRS-ETE has been thankfully acknowledged.

\section{References}

1. Anaya NM, Faghihzadeh F, Ganji 2, Bothun G, Oyanedel-Craver V (2016a) Comparative study between chemostat and batch reactors to quantify membrane permeability changes on bacteria exposed to silver nanoparticles. Sci Total Environ. 565:841-848. doi: 10.1016/j.scitotenv.2016.03.039

2. Anaya NM, Solomona F, Oyanedel-Craver V (2016) Effects of dysprosium oxide nanoparticles on Escherichia coli. Environ Sci NANO 3:67-73

3. Applerot G, Lipovsky A, Dror R, Perkas N, Nitzan Y, Lubart R, Gedanken A (2009) Enhanced antibacterial activity of nanocrystalline $\mathrm{ZnO}$ due to increased ROS-mediated cell injury. Adv Funct Mater 19:842-852

4. Arora S, Rajwade JM, Paknikar KM (2012) Nanotoxicology and in vitro studies: the need of the hour. Toxicol Appl Pharmacol 258:151-165

5. Azam A, Ahmed AS, Oves M, Khan MS, Habib SS, Memic A (2012) Antimicrobial activity of metal oxide nanoparticles against Gram-positive and Gram-negative bacteria: a comparative study. Int J Nanomedicine 7:6003-6009

6. Baek YW, An YJ (2011) Microbial toxicity of metal oxide nanoparticles $\left(\mathrm{CuO}, \mathrm{NiO}, \mathrm{ZnO}\right.$, and $\left.\mathrm{Sb}_{2} \mathrm{O}_{3}\right)$ to Escherichia coli, Bacillus subtilis, and Streptococcus aureus. Sci Total Environ 409:1603-1608

7. Beddow J, Stolpe B, Cole P, Lead J, Sapp M, Lyons B, Colbeck I, Whitby C (2014) Effects of engineered silver nanoparticles on the growth and activity of ecologically important microbes. Environ Microbiol Rep 6:448-458

8. Borm PJ, Robbins D, Haubold S et al (2006) The potential risks of nanomaterials: a review carried out for ECETOC. Part Fibre Toxicol. doi:10.1186/1743-8977-3-11

9. Brar SK, Verma M, Tyagi RD, Surampalli RY (2010) Engineered nanoparticles in wastewater and wastewater sludge-evidence and impacts. Waste Manag 30:504-520

10. Cherchi C, Chernenko T, Diem M, Gu AZ (2011) Impact of nano titanium dioxide exposure on cellular structure of anabaena variabilis and evidence of internalization. Environ Toxicol Chem 30:861-869

11. Choi O, Deng KK, Kim NJ, Ross L, Surampalli RY, Hu Z (2008) The inhibitory effects of silver nanoparticles, silver ions, and silver chloride colloids on microbial growth. Water Res 42:3066-3074

12. Chudasama B, Vala AK, Andhariya N, Mehta RV, Upadhyay RV (2010) Highly bacterial resistant silver nanoparticles: synthesis and antibacterial activities. J Nanopart Res 12:1677-1685

13. Chung H, Son Y, Yoon TK, Kim S, Kim W (2011) The effect of multi-walled carbon nanotubes on soil microbial activity. Ecotoxicol Environ Safety 74:569-575

14. Cledon M, Brar sk, Zhang TC (2015) Nano-ecotoxicology of natural and engineered nanomaterials for microorganisms. In: Brar SK, Zhang TC, Verma M, Surampalli RY, Tyagi RD (eds) Nanomaterials in the environment, 1st edn. American Society of Civil Engineers, USA, pp 439-467

15. Collins D, Luxton T, Kumar N, Shah S, Walker VK, Shah V (2012) Assessing the impact of copper and zinc oxide nanoparticles on soil: a field study. PLoS One. doi:10.1371/journal.pone. 0042663

16. Dinesh R, Anandaraj M, Srinivasan V, Hamza S (2012) Engineered nanoparticles in the soil and their potential implications to microbial activity. Geoderma 173-174:19-27

17. Duvall MN, Wyatt AM (2011) Regulation of nanotechnology and nanomaterials at EPA and around the world: recent developments and context. http://www.bdlaw.com/assets/attachments/299.pdf. Accessed 12 April 2016

18. ECHA web resource. http://echa.europa.eu/regulations/nanoma terials. Accessed 12 April 2016

19. Eduok S, Martin B, Villa R, Nocker A, Jefferson B, Coulon F (2013) Evaluation of engineered nanoparticle toxic effect on wastewater microorganisms: current status and challenges. Ecotoxicol Environ Safety 95:1-9

20. Eisenberg D, Grieger K, Hristozov D, Bates M, Linkov I (2015) Risk assessment, life cycle assessment, and decision methods for nanomaterials. In: Brar SK, Zhang TC, Verma M, Surampalli RY, Tyagi RD (eds) Nanomaterials in the environment, 1st edn. American Society of Civil Engineers, USA, pp 382-419

21. El Badawy AM, Luxton TP, Silva RG, Scheckel KG, Suidan MT, Tolaymat TM (2010) Impact of environmental conditions (pH, ionic strength, and electrolyte type) on the surface charge and aggregation of silver nanoparticles suspensions. Environ Sci Technol 44:1260-1266

22. European Commission web resource. http://ec.europa.eu/ research/industrial_technologies/policy_en.html. Accessed 12 April 2016

23. Faghihzadeh F, Anaya MN, Schifman LA, Oyanedel-Craver V (2016) Fourier transform infrared spectroscopy to assess molecular-level changes in microorganisms exposed to nanoparticles. Nanotechnol Environ Eng. doi:10.1007/s41204-016-0001-8

24. FDA web resource. http://www.fda.gov/ScienceResearch/Spe cialTopics/Nanotechnology/ucm301114.htm. Accessed 12 April 2016

25. Flores M, Colon N, Rivera O, Villalba N, Baez Y, Quispitupa D, Avalos J, Perales O (2004) A study of the growth curves of $C$. xerosis and E. coli bacteria in mediums containing cobalt ferrite nanoparticles. Mat Res Soc Symp Proc. doi:10.1557/PROC-820O8.17

26. Frenk S, Ben-Moshe T, Dror I, Berkowitz B, Minz D (2013) Effect of metal oxide nanoparticles on microbial community structure and function in two different soil types. PLoS One. doi:10.1371/journal.pone.0084441

27. Gajewicz A, Rasulev B, Dinadayalane TC, Urbaszek P, Puzyn T, Leszczynska D, Leszczynski J (2012) Advancing risk assessment of engineered nanomaterials: application of computational approaches. Adv Drug Deliv Rev 64:1663-1693 
28. Gao J, Wang Y, Hovsepyan A, Bonzongo JC (2011) Effects of engineered nanomaterials on microbial catalyzed biogeochemical processes in sediments. J Hazard Mater 186:940-945

29. Ge Y, Schimel JP, Holden PA (2011) Evidence for negative effects of $\mathrm{TiO}_{2}$ and $\mathrm{ZnO}$ nanoparticles on soil bacterial communities. Environ Sci Technol 45:1659-1664

30. Goodwin DG, Marsh KM, Sosa IB, Payne JB, Gorham JM, Bouwer EJ, Fairbrother DH (2015) Interactions of microorganisms with polymer nanocomposite surfaces containing oxidized carbon nanotubes. Environ Sci Technol 49:5484-5492

31. Gottschalk F, Sonderer T, Scholz RW, Nowack B (2009) Modeled environmental concentrations of engineered nanomaterials $\left(\mathrm{TiO}_{2}, \mathrm{ZnO}, \mathrm{Ag}, \mathrm{CNT}\right.$, Fullerenes) for different regions. Environ Sci Technol 43:9216-9222

32. Green CJ, Ndegwa S (2011) Nanotechnology: a review of exposure, health risks and recent regulatory developments. National Collaborating Centre for Environmental Health. http:// www.ncceh.ca/sites/default/files/Nanotechnology_Review_Aug_ 2011.pdf. Accessed 11 May 2014

33. Guzmán E, Liggieri L, Santini E, Ferrari M, Ravera F (2012) Influence of silica nanoparticles on dilational rheology of DPPC-palmitic acid Langmuir monolayers. Soft Matter 8:3938-3948

34. Hang MN, Gunsolus IL, Wayland H, Melby ES et al (2016) Impact of nanoscale lithium nickel manganese cobalt oxide (NMC) on the bacterium Shewanella oneidensis MR-1. Chem Mater 28:1092-1100

35. Hegde K, Goswami R, Sarma SJ, Veeranki VD, Brar SK (2015b) Nano-ecotoxicology of natural and engineered nanomaterials for different ecosystems. In: Brar SK, Zhang TC, Verma M, Surampalli RY, Tyagi RD (eds) Nanomaterials in the environment, 1st edn. American Society of Civil Engineers, USA, pp 487-511

36. Hegde K, Goswami R, Sarma SJ, Veeranki VD, Brar SK, Surampalli RY (2015a) Environmental hazards and risks of nanomaterials. In: Brar SK, Zhang TC, Verma M, Surampalli RY, Tyagi RD (eds) Nanomaterials in the environment, 1st edn. American Society of Civil Engineers, USA, pp 357-382

37. Heinlaan M, Ivask A, Blinova I, Dubourguier HC, Kahru A (2008) Toxicity of nanosized and bulk $\mathrm{ZnO}, \mathrm{CuO}$ and $\mathrm{TiO}_{2}$ to bacteria Vibrio fischeri and crustaceans Daphnia magna and Thamnocephalus platyurus. Chemosphere 71:1308-1316

38. Hessler CM, Wu MY, Xue Z, Choi H, Seo Y (2012) The influence of capsular extracellular polymeric substances on the interaction between $\mathrm{TiO}_{2}$ nanoparticles and planktonic bacteria. Water Res 46:4687-4696

39. Holden PA, Schimel JP, Godwin HA (2014) Five reasons to use bacteria when assessing manufactured nanomaterial environmental hazards and fates. Curr Opin Biotechnol 27:73-78

40. Hyung H, Fortner JD, Hughes JB, Kim JH (2007) Natural organic matter stabilizes carbon nanotubes in the aqueous phase. Environ Sci Technol 41:179-184

41. Jafar G, Hamzeh G (2013) Ecotoxicity of nanomaterials in soil. Ann Biol Res 4:86-92

42. Jiang W, Mashayekhi H, Xing B (2009) Bacterial toxicity comparison between nano- and micro-scaled oxide particles. Environ Pollut 157:1619-1625

43. Jin X, Li M, Wang J, Marambio-Jones C, Peng F, Huang X, Damoiseaux R, Hoek EMV (2010) High-throughput screening of silver nanoparticle stability and bacterial inactivation in aquatic media: influence of specific ions. Environ Sci Technol 44:7321-7328

44. Kahru A, Dubourguier HC (2010) From ecotoxicology to nanoecotoxicology. Toxicology 269:105-119

45. Kang S, Pinault M, Pfefferle LD, Elimelech M (2007) Singlewalled carbon nanotubes exhibit strong antimicrobial activity. Langmuir 23:8670-8673
46. Kiser MA, Ryu H, Jang H, Hristovski K, Westerhoff P (2010) Biosorption of nanoparticles to heterotrophic wastewater biomass. Water Res 44:4105-4114

47. Klaine SJ, Alvarez PJJ, Batley GE, Fernandes TF, Handy RD, Lyon DY, Mahendra S, McLaughlin MJ, Lead JR (2008) Nanomaterials in the environment: behavior, fate, bioavailability, and effects. Environ Toxicol Chem 27:1825-1851

48. Lee C, Kim JY, Lee WI, Nelson KL, Yoon J, Sedlak DL (2008) Bactericidal effect of zero-valent iron nanoparticles on Escherichia coli. Environ Sci Technol 42:4927-4933

49. Li M, Pokhrel S, Jin X, Maedler L, Damoiseaux R, Hoek EMV (2011) Stability, bioavailability, and bacterial toxicity of $\mathrm{ZnO}$ and iron-doped $\mathrm{ZnO}$ nanoparticles in aquatic media. Environ Sci Technol 45:755-761

50. Li Y, Zhang W, Niu J, Chen Y (2012) Mechanism of photogenerated reactive oxygen species and correlation with the antibacterial properties of engineered metal-oxide nanoparticles. ACS Nano 6:5164-5173

51. Liu L, Sun L, Zhong Z, Zhu J, Song H (2016) Effects of titanium dioxide nanoparticles on intestinal commensal bacteria. Nucl Sci Tech. doi:10.1007/s41365-016-0011-z

52. Liu Y, He L, Mustapha A, Li H, Hu ZQ, Lin M (2009) Antibacterial activities of zinc oxide nanoparticles against Escherichia coli O157:H7. J Appl Microbiol 107:1193-1201

53. Lok CN, Ho CM, Chen R, He QY, Yu WY, Sun HZ, Tam PKH, Chiu JF, Che CM (2006) Proteomic analysis of the mode of antibacterial action of silver nanoparticles. J Proteome Res 5:916-924

54. Luo Z, Chen Z, Qiu Z, Li Y, Laing GD, Liu A, Yan C (2015) Gold and silver nanoparticle effects on ammonia-oxidizing bacteria cultures under ammoxidation. Chemosphere 120:737-742

55. Lyon DY, Alvarez PJ (2008) Fullerene water suspension (nC60) exerts antibacterial effects via ROS-independent protein oxidation. Environ Sci Technol 42:8127-8132

56. Masrahi A, VandeVoort AR, Arai Y (2014) Effects of silver nanoparticle on soil-nitrification processes. Arch Environ Contam Toxicol 66:504-513

57. Maurer-Jones MA, Gunsolus IL, Murphy CJ, Haynes CL (2013) Toxicity of engineered nanoparticles in the environment. Anal Biochem 85:3036-3049

58. Merceda T, Santosa S, Riveraa O, Villalbaa N, Baeza Y, Gaudiera J, Avalosa J, Peralesa O, Tomara MS, Parra-Palominoa A, Avalosa J (2006) Effect of zinc oxide nanocrystals in media containing E. coli and C. xerosis bacteria. MRS Proc. doi:10. 1557/PROC-0900-O03-08

59. Morose G (2010) The 5 principles of "Design for Safer Nanotechnology". J Clean Prod 18:285-289

60. Mukherjee A, Majumdar S, Servin AD, Pagano L, Dhankher OP, White JC (2016) Carbon nanomaterials in agriculture: a critical review. Front Plant Sci 7:172. doi:10.3389/fpls.2016.00172

61. NanoPortal. http://nanoportal.gc.ca/default.asp?lang=En\&n= 23410d1f-1. Accessed 12 April 2016

62. Navarro E, Baun A, Behra R, Hartmann NB, Filser J, Miao A, Quigg A, Santschi PH, Sigg L (2008) Environmental behavior and ecotoxicity of engineered nanoparticles to algae, plants, and fungi. Ecotoxicology 17:372-386

63. Navarro E, Piccapietra F, Wagner B, Marconi F, Kaegi R, Odzak N, Sigg L, Behra R (2008) Toxicity of Silver Nanoparticles to Chlamydomonas reinhardtii. Environ Sci Technol 42:8959-8964

64. OECD (2012) Important issues on risk assessment of manufactured nanomaterials. http://www.oecd.org/officialdocuments/pub licdisplaydocumentpdf/?cote=env/jm/mono(2012)8\&doclanguage $=$ en. Accessed 11 May 2014

65. Park CM, Chu KH, Heo J, Her N, Jang M, Son A, Yoon Y (2016) Environmental behavior of engineered nanomaterials in porous media: a review. J Hazard Mater 309:133-150 
66. Pelletier DA, Suresh AK, Holton GA, McKeown CK et al (2010) Effects of engineered cerium oxide nanoparticles on bacterial growth and viability. Appl Environ Microbiol 76:7981-7989

67. Petosa AR, Jaisi DP, Quevedo IR, Elimelech M, Tufenkji N (2010) Aggregation and deposition of engineered nanomaterials in aquatic environments: role of physicochemical interactions. Environ Sci Technol 44:6532-6549

68. Pokhrel LR, Silva T, Dubey B, El Badawy AM, Tolaymat TM, Scheuerman PR (2012) Rapid screening of aquatic toxicity of several metal-based nanoparticles using the MetPLATE ${ }^{\mathrm{TM}}$ bioassay. Sci Total Environ 426:414-422

69. Praetorius A, Arvidsson R, Molander S, Scheringer M (2013) Facing complexity through informed simplifications: a research agenda for aquatic exposure assessment of nanoparticles. Environ Sci Process Impact 15:161-168

70. Pulicharla R, Brar SK, Verma M, Surampalli RY, Zhang TC (2015) Behavior and fate of natural and engineered nanomaterials in soils. In: Brar SK, Zhang TC, Verma M, Surampalli RY, Tyagi RD (eds) Nanomaterials in the environment (1st edn). American Society of Civil Engineers, USA, pp 291-314

71. Rajkishore SK, Subramanian KS, Natarajan N, Gunasekaran K (2013) Nanotoxicity at various trophic levels: a review. Bioscan 8:975-982

72. Rana S, Kalaichelvan PT (2013) Ecotoxicity of nanoparticles. ISRN Toxicol. doi:10.1155/2013/574648

73. Rodrigues DF, Jaisi DP, Elimelech M (2013) Toxicity of functionalized single-walled carbon nanotubes on soil microbial communities: implications for nutrient cycling in soil. Environ Sci Technol 47:625-633

74. Rousk J, Rousk K, Curling SF, Jones DL (2012) Comparative toxicity of nanoparticulate $\mathrm{CuO}$ and $\mathrm{ZnO}$ to soil bacterial communities. PLoS One. doi:10.1371/journal.pone.0034197

75. Savolainen K, Alenius H, Norppa H, Pylkkanen L, Tuomi T, Kasper G (2010) Risk assessment of engineered nanomaterials and nanotechnologies - a review. Toxicology 269:92-104

76. Scown TM, van Aerle R, Tyler CR (2010) Review: do engineered nanoparticles pose a significant threat to the aquatic environment? Crit Rev Toxicol 40:653-670

77. Simon-Deckers A, Loo S, Mayne-Lahermite M, HerlinBoime N, Menguy N, Reynaud C, Gouget B, Carriè re M (2009) Size-, composition- and shape-dependent toxicological impact of metal oxide nanoparticles and carbon nanotubes toward bacteria. Environ Sci Technol 43:8423-8429

78. Simonet BM, Valcárcel M (2009) Monitoring nanoparticles in the environment. Anal Bioanal Chem 393:17-21

79. Song JE, Phenrat T, Marinakos S, Xiao Y, Liu J, Wiesner MR, Tilton RD, Lowry GV (2011) Hydrophobic interactions increase attachment of gum arabic- and PVP-coated Ag nanoparticles to hydrophobic surfaces. Environ Sci Technol 45:5988-5995

80. Sotiriou GA, Pratsinis SE (2010) Antibacterial activity of nanosilver ions and particles. Environ Sci Technol 44:5649-5654

81. Suppi S, Kasemets K, Ivask A, Künnis-Beres K, Sihtmäe M, Kurvet I, Aruoja V, Kahru A (2015) A novel method for comparison of biocidal properties of nanomaterials to bacteria, yeasts and algae. J Hazard Mater 286:75-84
82. Tegou E, Magana M, Katsogridaki AE, Ioannidis A, Raptis V, Jordan S, Chatzipanagiotou S, Chatzandroulis S, Ornelas C, Tegos GP (2016) Terms of endearment: bacteria meet graphene nanosurfaces. Biomaterials 89:38-55

83. Throback IN, Johansson M, Rosenquist M, Pell M, Hansson M, Hallin $S$ (2007) Silver (Ag+) reduces denitrification and induces enrichment of novel nirK genotypes in soil. FEMS Microbiol Lett 270:189-194

84. Tiede K, Hassell M, Breitbarth E, Chaudhry Q, Boxall ABA (2009) Considerations for environmental fate and ecotoxicity testing to support environmental risk assessments for engineered nanoparticles. J Chromatogr 1216:503-509

85. Tong Z, Bischoff M, Nies LF, Myer P, Applegate B, Turco RF (2012) Response of soil microorganisms to as-produced and functionalized single-wall carbon nanotubes (SWNTs). Environ Sci Technol 46:13471-13479

86. TSCA web resource. https://www.epa.gov/reviewing-new-chemi cals-under-toxic-substances-control-act-tsca/control-nanoscalematerials-under. Accessed 12 April 2016

87. Van Hoecke K, De Schamphelaere KAC, Ramirez-Garcia S, Van der Meeren P, Smagghe G, Janssen CR (2011) Influence of alumina coating on characteristics and effects of $\mathrm{SiO} 2$ nanoparticles in algal growth inhibition assays at various $\mathrm{pH}$ and organic matter contents. Environ Int 37:1118-1125

88. Van Hoecke K, Quik JTK, Mankiewicz-Boczek J, De Schamphelaere $\mathrm{KAC}$ et al (2009) Fate and effects of $\mathrm{CeO}_{2}$ nanoparticles in aquatic ecotoxicity tests. Environ Sci Technol 43:4537-4546

89. Vertelov GK, Krutyakov YA, Efremenkova OV, Olenin AY, Lisichkin GV (2008) A versatile synthesis of highly bactericidal Myramistin (R) stabilized silver nanoparticles. Nanotechnology. doi:10.1088/0957-4484/19/35/355707

90. Wu B, Zhuang WQ, Sahu M, Biswas P, Tang YJ (2011) Cudoped $\mathrm{TiO}_{2}$ nanoparticles enhance survival of Shewanella oneidensis MR-1 under Ultraviolet Light (UV) exposure. Sci Total Environ 409:4635-4639

91. Yang Y, Mathieu JM, Chattopadhyay S, Mille JT, Wu T, Shibata T, Guo W, Alvarez PJ (2012) Defense mechanisms of Pseudomonas aeruginosa PAO1 against quantum dots and their released heavy metals. ACS Nano 6:6091-6098

92. Yang Y, Quensen J, Mathieu J, Wang Q, Wang J, Li M, Tiedje JM, Alvarez PJ (2014) Pyrosequencing reveals higher impact of silver nanoparticles than $\mathrm{Ag}+$ on the microbial community structure of activated sludge. Water Res 48:317-325

93. Yang Y, Wang J, Zhu H, Colvin VL, Alvarez PJ (2012) Relative susceptibility and transcriptional response of nitrogen cycling bacteria to quantum dots. Environ Sci Technol 46:3433-3441

94. Yang Y, Yu Z, Nosaka T, Doudrick K, Hristovski K, Herckes P, Westerhoff $P$ (2015) Interaction of carbonaceous nanomaterials with wastewater biomass. Front Environ Sci Eng 9:823-831

95. Zou X, Zhang L, Wang Z, Luo Y (2016) Mechanisms of the antimicrobial activities of graphene materials. J Am Chem Soc 138:2064-2077 